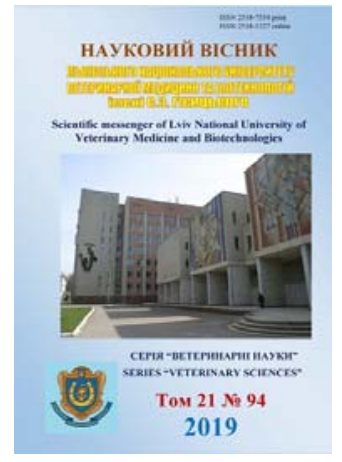

\author{
Науковий вісник Дьвівського національного університету \\ ветеринарної медицини та біотехнологій імені С.3. Гжицького. \\ Серія: Ветеринарні науки \\ Scientific Messenger of Lviv National University \\ of Veterinary Medicine and Biotechnologies. \\ Series: Veterinary sciences
}

UDC 636.09:639.1.09

\title{
State of the organism of the same year scaly carp infected by Eudiplozoon nipponicum
}

\author{
O.V. Fedorovych, B.V. Gutyj \\ Stepan Gzhytskyi National University of Veterinary Medicine and Biotechnologies Lviv, Ukraine
}

Article info

Received 24.04.2019

Received in revised form 24.05.2019

Accepted 27.05.2019

Stepan Gzhytskyi National University of Veterinary Medicine and Biotechnologies Lviv, Pekarska Str., 50, Lviv, 79010, Ukraine. Tel.: +38-063-983-08-02 E-mail:qnc_sn@ukr.net
Fedorovych, O.V., \& Gutyj, B.V. (2019). State of the organism of the same year scaly carp infected by Eudiplozoon nipponicum. Scientific Messenger of Lviv National University of Veterinary Medicine and Biotechnologies. Series: Veterinary sciences, 21(94), $146-151$. doi: $10.32718 /$ nvlvet 9427

One of the least studied monogeneses doses, for today, there is diplopic zoonosis of carp. Previously, it was believed that there is only one fish parasitize bothrium - Diplozoon paradoxum. However, in recent years it has been discovered and described already more than 10 species of pathogens of diplozoons, in particular Eudiplozoon nipponicum. Outbreaks of this disease are increasingly beginning to be recorded in fish ponds farms of the western region of Ukraine. Moreover, more often than in others in the amount of this parasite occurs in young fish. In view of the above, the purpose of our research was to investigate the degree of infestation of the same year scaly carp with the mentioned ectoparasite and study the changes that occur in morphological and biochemical composition of blood, intensity of peroxide processes, as well as the state of antioxidant and immune systems in invasive fish. The research was carried out in the garden and fish farms of the State Enterprise "Rybhosp"Galitskyi" (renamed LLC "Rybgosp "Burshtynskyi") IvanoFrankivsk region and FG "Dobrotvir fish factory" of Lviv region with the same year scaly carp. Two experiments were selected for the experiment groups of the same yaer of scaly carp (control-non-invasive fish and experimental - invasive with Eudiplozoon nipponicum) in 6 specimens of fish in each group of weights bodies 45-47 g. In experimental fish they were studied their infestation with ectoparasites, as well hematological parameters, protein content of the blood, peroxide intensity processes, the state of antioxidant and immune systems of non-invasive and invasive specimens. During the parasitological examination of both experimental fish farms was detected infestation in scaly carp caused by ectoparasites Epidipalous nipponicum. In May there was a pick of infected the same year scaly carps (2.87 and 3.10 eggs/fish). Infected fish, compared to non-invasive fish, there were significant changes in hematological parameters. In particular, in the blood of parasites affected by fish the number of erythrocytes decreased $(P<0.001)$, the hemoglobin content $(P<0.001)$ and hematocrit and increased number of leucocyte $(P<0.001)$. The infected scaly carp the above-mentioned parasite pressed by the protein-synthesizing function of the organism, as indicated a high $(P<0.001)$ reduction in total protein, albumin and $\alpha$-globulins in the blood serum, there is a depression in them humoral links of non-specific resistance and antioxidant system activity protection, and the content of products of peroxide oxidation of lipids in their hepatopancreas significantly increases.

Key words: the same year scaly carps, Eudiplozoon nipponicum, intensity and extensiveness of invasion, blood, hematological parameters, proteinblood composition, natural resistance, peroxide lipid oxidation, antioxidant system.

\section{Стан організму однорічок коропа лускатого за їх ураження збудником Eudiplozoon nipponicum}

\author{
О.В. Федорович, Б.В. Гутий
}

Львівський національний університет ветеринарної медицини та біотехнологій імені С.3. Гжицьккого, м. Львів, Україна 
Одним із найменш вивчених моногеноїдозів, на сьогоднішній день, є диплозооноз коропа. Раніше вважали, ияо у риб паразитує лиме один присисень - Diplozoоп рагаdохит. Однак за останні роки виявлено і описано уже більше 10 видів збудників диплозоонів, зокрема й Eudiplozoon пірропісит. Спалахи цьього захворювання все частіше почали реєструвати у рибницьких господарствах західного регіону Украӥни. Причому, частіше за все і в більшій кількості ией паразит зустрічається у молодих риб. 3 огляду на зазначене, метою наших досліджень було вивчити ступінь ураженості однорічок коропа лускатого вищенаведеним ектопаразитом та вивчити зміни, які відбуваються у морфологічному та біохімічному складі крові, інтенсивності пероксидних прочесів, а також стан антиоксидантної та імунної систем у інвазованої риби. Дослідження проведені у садково-рибних господарствах ДП “Рибгосп “Галицький” (перейменований у ТОВ “Рибгосп “Буритинський”) Івано-Франківської області та ФГ “Добротвірський рибзавод” Львівської області на однорічках коропа лускатого. Для проведення експерименту було відібрано дві групи однорічок коропа лускатого (контрольна - неінвазовані риби і дослідна - інвазовані Еидірlоzооп пірропісит) по 6 екземплярів риб у кожній групі масою тіла 45-47 г. У піддослідних риб вивчали їх ураженість ектопаразитом, а також гематологічні показники, білковий склад крові, інтенсивність пероксидних процесів, стан антиоксидантної та імунної систем неінвазованих і інвазованих екземплярів. За паразитологічного обстеження обох дослідних рибницьких садків було виявлено інвазію у однорічок коропа лускатого, спричинену ектопаразитами Еи diplozoоп пірропісит. Ураження однорічок коропа лускатого диплозоонами найінтенсивнішим було у травні (2,87 та 3,10 екз/рибу). У інвазованої риби, порівняно з неінвазованою спостерігалися значні зміни гематологічних показників. Зокрема, у крові уражених паразитами риб знижувалася кількість еритроцитів $(P<0,001)$, вміст гемоглобіну $(P<0,001)$ та гематокриту і підвищувалася кількість лейкоцитів $(P<0,001)$. У заражених однорічок коропа лускатого вищенаведеним диплозооном пригнічується протеїнсинтезуюча функція організму, на щуо вказує високодостовірне (P < 0,001) зниження вмісту загального протеїну, альбумінів та $\alpha$-глобулінів у сироватці крові, спостерігається пригнічення у них гуморальної ланки неспецифічної резистентності та активності системи антиоксидантного захисту, а вміст продуктів пероксидного окиснення ліпідів у їх гепатопанкреасі значно підвищується.

Ключові слова: однорічки коропа лускатого, Eudiplozoоп пірропісит, інтенсивність та екстенсивність інвазії, кров, гематологічні показники, білковий склад крові, природна резистентність, пероксидне окиснення ліпідів, антиоксидантна система.

\section{Ветуп}

В останне десятиліття антропогенної діяльності (безконтрольне ввезення посадкового матеріалу, ущільнені посадки риб, надмірне забруднення водойм органічними та мінеральними добривами) у вирощувальних ставах значно змінився склад паразитофауни. Зокрема, з'явилися нові інвазійні хвороби, а відомі захворювання почали проявлятись вже в інших формах, збільшилася частка моногенеозів (дактилогіроз, гіродактильоз, диплозооноз) тощо (Martyshuk et al., 2016; Loboiko et al., 2017; Grynevych, 2018; Goncharov, 2019). Одним із найменш вивчених моногеноїдозів, на сьогоднішній день, є диплозооноз коропа. Раніше вважали, що у риб паразитує лише один присисень Diplozoon paradoxum. Однак за останні роки виявлено і описано уже більше 10 видів збудників диплозоонів, зокрема й Eudiplozoon nipponicum (Zurawski et al., 2001; Valigurová et al., 2011; Roudnický et al., 2018). Спалахи цього захворювання все частіше почали реєструвати у рибницьких господарствах західного регіону України. Причому, частіше за все і в більшій кількості цей паразит зустрічається у молодих риб. Своїми присосками і прикріплюючими клапанами він травмує тканину зябер і руйнує зяброві пелюстки (Davyidov \& Temnihanov, 2004). Попередніми нашими дослідженнями (Stybel \& Fedorovych, 2015) вивчено особливості контактної взаємодії Eudiplozoon nipponicum 3 тканиною зябрового апарату хазяїна та встановлено, що у системі “паразит-хазяїн” відбувається не тільки механічний контакт, але й адгезивний, який посилює потогенну дію гельмінта на організм риби. Внаслідок цієї дії відбувається порушення в кровопостачанні, газообміні органів тощо. 3 огляду на зазначене, метою наших досліджень було вивчити ступінь ураженості однорічок коропа лускатого вищенаведеним ектопаразитом та вивчити зміни, які відбуваються у морфологічному та біохімічному складі крові, інтенсивності пероксидних процесів, а також стан антиоксидантної та імунної систем у інвазованої риби.

\section{Матеріал і методи досліджень}

Дослідження проведені у садково-рибних господарствах ДП "Рибгосп “Галицький” (перейменований у ТОВ “Рибгосп “Бурштинський”) Івано-Франківської області та ФГ “Добротвірський рибзавод” Львівської області на однорічках коропа лускатого. Для проведення експерименту було відібрано дві групи однорічок коропа лускатого (контрольна - неінвазовані риби і дослідна - інвазовані Eudiplozoon nipponicum) по 6 екземплярів риб у кожній групі масою тіла 45-47 г. У піддослідних риб вивчали їх ураженість ектопаразитом, а також гематологічні показники, білковий склад крові, інтенсивність пероксидних процесів, стан антиоксидантної та імунної систем неінвазованих і інвазованих екземплярів.

Паразитологічне дослідження риби проводили методом неповного паразитологічного розтину за И.Е. Быховской-Павловской (Bykhovskaya-Pavlovskaya, 1985). Упродовж усього дослідного періоду гідрохімічні показники води були в межах норми. Видову належність паразитів визначали за “Определитель паразитов пресноводных рыб фауны СССР” (Bauer, 1987).

Збір матеріалу та паразитологічний розтин проводили як в польових, так і в лабораторних умовах. Зібраний при цьому матеріал служив об'єктом для паразитологічних досліджень 3 метою вивчення морфофункціональних взаємовідносин паразита і риби.

Екстенсивність інвазії (ЕI) визначали за формулою:

$$
E I=\frac{X}{Y} \times 100 \% \text {, }
$$

де $\mathrm{X}$ - кількість риб, у яких виявили паразитів, $\mathrm{Y}$ загальна кількість досліджуваних риб. Інтенсивність інвазії (II) визначали шляхом підрахунку кількості паразитів на тілі досліджуваної риби. 
Для біохімічних досліджень від неінвазованих та інвазованих риб відбирали кров з серця за допомогою голки і шприца. Проби стабілізували гепарином 3 розрахунку 10 од./мл. Визначення вмісту гемоглобіну проводили гемоглобін-ціанідним методом (з ацетонціангідрином). Гематокритну величину визначали на мікроцентрифузі гематокритній МЦГ-8. Кількість еритроцитів підраховували шляхом дослідження крові за фотоелектроколориметричним методом з використанням каліброваних графіків. Кількість лейкоцитів підраховували у лічильній камері Горяєва (Kondrahin et al., 1985).

Вміст загального протеїну у сироватці крові риб визначали за біуретовою реакцією (Kondrahin et al., 1985). Метод базується на утворенні у лужному середовищі білками сироватки крові з сірчанокислою міддю сполук, зафарбованих у фіолетовий колір. Співвідношення окремих білкових фракцій визначали шляхом електрофоретичного розділення у поліакриламідному гелі (Mauer, 1971).

Природну резистентність піддослідних риб вивчали за комплексом гуморальних факторів крові (лізоцимну, бактерицидну активність сироватки крові, фагоцитарну активність нейтрофілів крові, фагоцитарний індекс та фагоцитарне число). Рівень продуктів пероксидного окиснення ліпідів (ПОЛ), активність ферментів антиоксидантної системи (АОС) риб визначали в гепатопанкреасі. Інтенсивність процесів ПОЛ оцінювали за вмістом у гепатопанкреасі ТБКактивних продуктів, дієнових кон'югатів та гідропероксидів ліпідів. Антиоксидантні властивості досліджуваної тканини визначали за активністю супероксиддисмутази (СОД), каталази та глутатіонпероксидази. Показники природної резистентності, ПОЛ та АОС вивчали за методиками, описаними у довіднику “Лабораторні методи досліджень у біології, тваринництві та ветеринарній медицині” (Vlizlo, 2012).

Одержані дані наукових досліджень обробляли методом варіаційної статистики за Г.Ф. Лакиным (Lakin, 1990) з використанням комп'ютерних програм "Excel” та "Statistica 6.1". Результати середніх значень вважали статистично вірогідними при $\mathrm{P}<0,05(*)$, $\mathrm{P}<0,01(* *), \mathrm{P}<0,001(* * *)$.

\section{Результати та їх обговорення}

При обстеженні однорічок коропа лускатого нами був виявлений ектопаразит Eudiplozoon nipponicum, який на сьогоднішній день $\epsilon$ майже не вивченим (табл. 1). Екстенсивність інвазії цим паразитом у ДП "Рибгосп “Галицький” у травні становила $10 \%$, а інтенсивність інвазії - 2,87 екз./рибу. Це більше, ніж у липні відповідно на 5\% та 0,37 екз./рибу. Середня ЕІ впродовж вегетаційного періоду у рибницьких садках господарства становила $7,5 \%$, середня II 2,69 екз./рибу.

\section{Таблиця 1}

Ураженість однорічок коропа ектопаразитом Eudiplozoon nipponicum $(\mathrm{n}=20)$

\begin{tabular}{llcc}
\hline \multirow{2}{*}{ Господарство } & \multirow{2}{*}{ Місяці } & \multicolumn{2}{c}{ Eudiplozoon nipponicum } \\
\cline { 3 - 4 } & березень & EI, \% & II, екз./рибу \\
\hline \multirow{2}{*}{ ДП “Рибгосп } & травень & 10 & - \\
“Галицький” & липень & 5 & 2,87 \\
& вересень & - & - \\
\hline \multirow{2}{*}{ ФГ “Добротвір- } & березень & - & - \\
ський рибзавод” & травень & 15 & 3,10 \\
& липень & 10 & 2,72 \\
& вересень & - & - \\
\hline
\end{tabular}

У ФГ “Добротвірський рибзавод” екстенсивність та інтенсивність інвазії були дещо вищими: у травні ці показники становили відповідно $15 \%$ та 3,10 екз./рибу, що більше, ніж у липні на 5\% та 0,38 екз./рибу. Середня ЕІ впродовж вегетаційного періоду у рибницьких садках господарства становила $12,5 \%$, середня II - 2,91 екз./рибу.

Таким чином, за паразитологічного обстеження дослідних рибницьких садків було виявлено інвазію у однорічок коропа лускатого, спричинену ектопаразитами Eudiplozoon nipponicum. Ураження однорічок коропа лускатого диплозоонами найінтенсивнішим було у травні.

Відомо, що кров є однією з перших систем, яка швидко і адекватно реагує на несприятливі фактори зовнішнього середовища, в т. ч. і на розвиток різних захворювань. Порушення фізіологічного стану риб під дією токсичного агента відображається на гематологічних показниках. Нами встановлено зміни гематологічних показників однорічок коропа, уражених Eudiplozoon nipponicum (табл. 2). Кількість еритроцитів у крові коропа, ураженого збудником диплозоонозу порівняно 3 неінвазованою рибою зменшилася на 0,44 Т/л, вміст гемоглобіну - на 7,97 г/л $(\mathrm{P}<0,001)$, вміст гематокриту - на 0,02 л/л, кількість лейкоцитів, навпаки, зросла на 10,81 Г/л (Р <0,001).

\section{Таблиця 2}

Гематологічні показники однорічок коропа, уражених Eudiplozoon nipponicum, $\mathrm{M} \pm \mathrm{m}(\mathrm{n}=6)$

\begin{tabular}{lrc}
\hline \multicolumn{1}{c}{ Показник } & \multicolumn{2}{c}{ Група риб } \\
\cline { 2 - 3 } & контрольна & дослідна \\
\hline Еритроцити, Т/л & $1,22 \pm 0,044$ & $0,78 \pm 0,044^{* * *}$ \\
Гемоглобін, Г/л & $83,22 \pm 0,952$ & $75,25 \pm 0,827 * * *$ \\
Гематокрит, л/л & $0,25 \pm 0,010$ & $0,23 \pm 0,007$ \\
Лейкоцити, Г/л & $26,72 \pm 0,290$ & $37,53 \pm 1,010^{* * *}$ \\
\hline
\end{tabular}

Примітка: ***- $\mathrm{P}<0,001-$ порівняно $з$ контрольною групою 
Таким чином, у однорічок коропа лускатого, уражених диплозоонами, порівняно 3 неінвазованою рибою спостерігалися значні зміни гематологічних показників. Зокрема, у крові уражених паразитами риб знижувалася кількість еритроцитів, вміст гемоглобіну та гематокриту і підвищувалася кількість лейкоцитів.

Відомо, що білки крові визначають транспортні, захисні функції, беруть участь у регуляції кислотнолужного стану організму, є також антитілами і регуляторами згортання крові. Тому їх вміст у крові виступає досить важливим діагностичним параметром у ряді захворювань, які особливо пов'язані з порушенням метаболізму. Фізіологічний стан однорічок коропа лускатого i, зокрема, вміст у сироватці їх крові загального протеїну та співвідношення окремих його фракцій також певною мірою змінювалися за ураженості моногенеями (табл. 3). Так, у риб, інвазованих Eudiplozoon nipponicum, порівняно 3 неураженою рибою вміст загального протеїну зменшився на 3,67 г/л $(\mathrm{P}<0,001)$, альбумінів - на 2,83 г/л $(\mathrm{P}<0,001)$ та глобулінів - на 0,84 г/л $(\mathrm{P}<0,001)$. У той же час відносний вміст альбумінів у сироватці крові дослідних риб порівняно з контролем був меншим на 2,56, а глобулінів - більшим на 2,56\%.

Збудник диплозоонозу впливав також на фракційний склад білка сироватки крові риб. В уражених паразитами особин порівняно з контролем спостерігалося зниження вмісту $\alpha$ - і $\gamma$-глобулінів (відповідно на $1,25(\mathrm{P}<0,001)$ і 0,20 г/л) та достовірне збільшення вмісту $\beta$-глобулінів (на 0,61 г/л $(\mathrm{P}<0,05))$.

\section{Таблиця 3}

Білковий склад сироватки крові однорічок коропа, інвазованих Eudiplozoon nipponicum, $\mathrm{M} \pm \mathrm{m}(\mathrm{n}=6)$

\begin{tabular}{crc}
\hline Показник & \multicolumn{3}{c}{ Група риб } \\
\cline { 2 - 3 } Протеїн загальний, г/л & конрольна & дослідна \\
\hline альбуміни, г/л & $40,37 \pm 0,307$ & $36,70 \pm 0,250^{* * *}$ \\
глобуліни, г/л & $20,85 \pm 0,409$ & $18,02 \pm 0,341^{* * *}$ \\
альбуміни, \% & $19,52 \pm 0,199$ & $18,68 \pm 0,118^{* *}$ \\
глобуліни, \% & $51,64 \pm 0,690$ & $49,08 \pm 0,622^{*}$ \\
$\alpha$-глобуліни, г/л & $48,36 \pm 0,690$ & $50,92 \pm 0,622^{*}$ \\
$\beta$-глобуліни, г/л & $8,73 \pm 0,122$ & $7,48 \pm 0,211^{* * *}$ \\
$\gamma$-глобуліни, г/л & $6,67 \pm 0,233$ & $7,28 \pm 0,131^{*}$ \\
$\alpha-$-гобуліни, \% & $4,12 \pm 0,180$ & $3,92 \pm 0,236$ \\
$\beta$-глобуліни, \% & $44,75 \pm 0,465$ & $40,06 \pm 1,170^{* *}$ \\
$\gamma$-глобуліни, \% & $34,17 \pm 1,194$ & $39,01 \pm 0,918^{* *}$ \\
А/Г коефіціснт & $21,08 \pm 0,845$ & $20,93 \pm 1,695$ \\
\end{tabular}

Примітка: *-P $<0,05, * *-\mathrm{P}<0,01, * * *-\mathrm{P}<0,001-$ порівняно 3 контрольною групою

У відсотковому значенні спостерігалася дещо інша картина: вміст $\alpha$-глобулінів у дослідної риби порівняно 3 контролем зменшився на 4,69, $\gamma$-глобулінів - на $0,15 \%$, а $\beta$-глобулінів збільшився на 4,84\%.

Альбуміново-глобуліновий коефіцієнт у неураженої риби був вірогідно вищим, ніж у інвазованої Eudiplozoon nipponicum, на 0,10 $(\mathrm{P}<0,05)$.

Таким чином, за інвазії однорічок коропа лускатого вищенаведеним диплозооном пригнічується білоксинтезуюча функція організму риб, на що вказує зниження вмісту загального білка, альбумінів та $\alpha$ глобулінів у сироватці крові.
Імунна система організму риб однією з перших реагує на зовнішні подразники. Вона тісно пов'язана 3 системою антиоксидантного захисту організму, оскільки при зниженні гуморального, неспецифічного i клітинного імунітетів знижується активність антиоксидантної системи та зростає інтенсивність перекисного окиснення ліпідів та утворення вільних радикалів, які $\epsilon$ шкідливими для клітин організму (Tushnytska, 2009). У однорічок коропа, уражених Eudiplozoon nipponicum, показники неспецифічної резистентності порівняно 3 неінвазованою рибою достовірно знизилися (табл. 4).

\section{Таблиця 4}

Показники неспецифічної резистентності у крові однорічок коропа, інвазованих Eudiplozoon nipponicum, $\mathrm{M} \pm \mathrm{m}$ $(\mathrm{n}=6)$

\begin{tabular}{|l|c|c|}
\hline \multicolumn{1}{|c|}{ Показник } & \multicolumn{2}{|c|}{ Група риб } \\
\cline { 2 - 3 } & контрольна & \multicolumn{2}{|c|}{ дослідна } \\
\hline Лізоцимна активність, \% & $39,30 \pm 0,480$ & $25,55 \pm 0,229 *$ \\
\hline Бактерицидна активність, \% & $27,40 \pm 0,727$ & $36,90 \pm 0,262 * *$ \\
\hline Фагоцитарна активність, \% & $39,23 \pm 0,659$ & $10,29 \pm 0,153 * *$ \\
\hline Фагоцитарний індекс, од. & $11,40 \pm 0,263$ & $3,80 \pm 0,080^{* *}$ \\
\hline Фагоцитарне число, од. & $4,48 \pm 0,161$ & \\
\hline
\end{tabular}

Примітка: ${ }^{*}-\mathrm{P}<0,05, * *-\mathrm{P}<0,01, * * *-\mathrm{P}<0,001-$ порівняно 3 контрольною групою 
Різниця між вищеназваними групами риб за показниками лізоцимної активності сироватки крові складала 1,98 (Р < 0,01), бактерицидної активності - 1,85 $(\mathrm{P}<0,05)$ фагоцитарної активності нейтрофілів крові $-2,33 \%(\mathrm{P}<0,01)$, фагоцитарного індексу $-1,11(\mathrm{P}<$ $0,01)$ та фагоцитарного числа $-0,68$ од. $(\mathrm{P}<0,01)$ на користь неуражених риб.

Отже, за прояву диплозоонозу в однорічок коропа спостерігалося пригнічення у них гуморальної ланки неспецифічної резистентності.

Процеси пероксидного окиснення ліпідів (ПОЛ) і стан антиоксидантної системи $\epsilon$ інформативними показниками для оцінки ступеня впливу токсикантів на організм, які можуть бути використані у розробці програм біомоніторингу. Активація ПОЛ розглядається як універсальна відповідь живої системи на дію екстремальних чинників. У будь-якому організмі за нормальних умов інтенсивність ПОЛ підтримується на певному стаціонарному рівні, що забезпечується системою антиоксидантного захисту, до якої належать антиоксидантні ферменти і низькомолекулярні сполуки (Goncharov, 2019). У літературних джерелах майже відсутні дані щодо змін ферментативної ланки антиоксидантної системи у коропових риб за дії ектопаразитів.

При з'ясуванні патогенної дії збудників Eudiplozoon nipponicum на організм однорічок коропа лускатого встановлено стимулюючий вплив їх життєдіяльності на утворення у гепатопанкреасі риб продуктів ПОЛ, що зумовлено високою інтенсивністю енергетичних процесів у цьому органі, які супроводжуються утворенням активних форм кисню (табл. 5). Зокрема вміст ТБК-продуктів у гепатопанкреасі ураженої риби порівняно 3 неураженою збільшився на 3,71 нмоль/мг білка $(\mathrm{P}<0,001)$ або на $66,8 \%$.

Про патогенну дію Eudiplozoon nipponicum на організм однорічок коропа лускатого свідчить також збільшення у їх гепатопанкреасі вмісту дієнових кон'югатів - на 0,41 нмоль/мг білка $(\mathrm{P}<0,001)$ або $22,8 \%$ та гідропероксидів ліпідів - на 1,32 од. опт. густ. /г (Р<0,01) або 59,5\%.

\section{Таблиця 5}

Рівень продуктів ПОЛ та активність ферментів АОС у гепатопанкреасі однорічок коропа, інвазованих Eudiplozoon nipponicum, $\mathrm{M} \pm \mathrm{m}(\mathrm{n}=6)$

\begin{tabular}{lrr}
\hline \multicolumn{1}{c}{ Показник } & \multicolumn{2}{c}{ Група риб } \\
\cline { 2 - 4 } ТБК-продукти, нмоль/мг білка & $5,55 \pm 0,024$ & донтрольна \\
Дієнові кон'югати, нмоль/мг білка & $1,80 \pm 0,026$ & $9,26 \pm 0,023 * * *$ \\
Гідропероксиди, од. опт. густ. / & $2,22 \pm 0,137$ & $3,54 \pm 0,310^{* *}$ \\
Супероксиддисмутаза, у.о./ мг білка & $5,43 \pm 0,025$ & $3,99 \pm 0,031^{* * *}$ \\
Каталаза, ммоль $\mathrm{H}_{2} \mathrm{O}_{2} /$ мг білка за хв $10^{-5}$ & $1,56 \pm 0,026$ & $1,50 \pm 0,016$ \\
Глутатіонпероксидаза, мкмоль GSH /мг білка за хв & $2,84 \pm 0,170$ & $2,45 \pm 0,184$ \\
\hline
\end{tabular}

Примітка: **-P $<0,01, * * *-\mathrm{P}<0,001-$ порівняно 3 контрольною групою

За ураження однорічок коропа диплозоонами спостерігалося зниження у їх гепатопанкреасі ферментів антиоксидантної системи. В інвазованої риби порівняно з неінвазованою активність супероксиддисмутази зменшилася на 1,44 у.о./ мг білка (P <0,001) або на $26,5 \%$, каталази - на 0,06 ммоль $\mathrm{H}_{2} \mathrm{O}_{2} /$ мг білка за $\mathrm{xB} \times 10^{-5}$ або на $3,8 \%$, глутатіонпероксидази - на 0,06 мкмоль GSH /мг білка за хв або на 13,7\%.

Отже, за ураження однорічок коропа лускатого диплозоонами вміст продуктів пероксидного окиснення ліпідів у їх гепатопанкреасі значно вищий, ніж у неінвазованих риб, а ферментативна активність системи антиоксидантного захисту - нижча.

\section{Висновки}

За паразитологічного обстеження обох дослідних рибницьких садків було виявлено інвазію у однорічок коропа лускатого, спричинену ектопаразитами Eudiplozoon nipponicum. Ураження однорічок коропа лускатого диплозоонами найінтенсивнішим було у травні (2,87 та 3,10 екз/рибу).

У інвазованої риби, порівняно 3 неінвазованою спостерігалися значні зміни гематологічних показників. Зокрема, у крові уражених паразитами риб зни- жувалася кількість еритроцитів (Р <0,001), вміст гемоглобіну $(\mathrm{P}<0,001)$ та гематокриту і підвищувалася кількість лейкоцитів $(\mathrm{P}<0,001)$.

У заражених однорічок коропа лускатого вищенаведеним диплозооном пригнічується протеїнсинтезуюча функція організму, на що вказує високодостовірне $(\mathrm{P}<0,001)$ зниження вмісту загального протеїну, альбумінів та $\alpha$-глобулінів у сироватці крові, спостерігається пригнічення у них гуморальної ланки неспецифічної резистентності та активності системи антиоксидантного захисту, а вміст продуктів пероксидного окиснення ліпідів у їх гепатопанкреасі значно підвищується.

Перспективи подальших досліджень. У подальшому буде вивчено ефективність лікування однорічок коропа лускатого препаратами "Бровермектин${\text { гранулят }{ }^{\mathrm{TM}} \text { " та “Авесстим }}^{\mathrm{TM}}$ ”.

\section{References}

Bykhovskaya-Pavlovskaya, E.I. (1985). Parazity ryb. Rukovodstvo po izucheniyu. L.: Nauka (in Russian).

Davyidov, O.N., \& Temnihanov, Yu.D. (2004). Bolezni presnovodnyih ryib. K.: Vetinform (in Russian). 
Goncharov, S. (2019). The morphological changes in the blood of the predatory fish species with eustrongylidosis. Scientific Messenger of Lviv National University of Veterinary Medicine and Biotechnologies. Series: Veterinary sciences, 21(93), 15-20. doi: 10.32718/nvlvet9303.

Grynevych, N. (2018). The dynamics of the physiological state changes and hematological indicators of the rainbow trout during the launch of the biofilter in the installations of the closed water utilization. Scientific Messenger of Lviv National University of Veterinary Medicine and Biotechnologies, 20(83), 19-24. doi: $10.15421 /$ nvlvet8304.

Kondrahin, I.P., Kurilova, N.V., \& Malahov, A.G. (1985). Klinicheskaja laboratornaja diagnostika v veterinari: spravochnoe izdanie. M.: Agropromizdat (in Russian).

Vlizlo, V.V. (2012). Laboratorni metody doslidzhen u biolohii, tvarynnytstvi ta veterynarnii medytsyni. Dovidnyk [za red. d. vet. n., prof., akademika NAAN V.V. Vlizla] Lviv, SPOLOM (in Ukrainian).

Lakin, G.F. (1990). Biometrija. M.: Vysshaja shkola (in Russian).

Loboiko, Yu., Barylo, B., \& Krushelnytska, O. (2017). Determination of the aminotransferase activity in tissues of infected with ectoparasites yearling carp. Scientific Messenger of Lviv National University of Veterinary Medicine and Biotechnologies, 19(79), 1721. doi: $10.15421 /$ nvlvet7904.

Martyshuk, T.V., Gutyj, B.V., \& Vishchur, O.I. (2016). Level of lipid peroxidation products in the blood of rats under the influence of oxidative stress and under the action of liposomal preparation of "Butaselmevit". Biological Bulletin of Bogdan Chmelnitskiy Melitopol State Pedagogical University, 6(2), 22-27. doi: $10.15421 / 201631$.
Mauer, G. (1971). Disk-elektroforez. Teorija i praktika jelektroforeza v poliakrilamidnom gele. Moskva: Mir (in Russian).

Bauer, O.N. (1987). Opredelitel parazitov presnovodnyih ryib faunyi SSSR: v 3 t. pod red. O.N. Bauera. L.: Nauka, 2, 584 (in Russian).

Roudnický, P., Vorel, J., Ilgová, J., Benovics, M., Norek, A., Jedličková, L., Mikeš, L., Potěšil, D., Zdráhal, Z., Dvořák, J., Gelnar, M., \& Kašný, M. (2018) Identification et caractérisation partielle d'un nouvelle serpine d'Eudiplozoon nipponicum (Monogenea, Polyopisthocotylea). Parasite, 25, 61. doi: 10.1051/parasite/2018062.

Stybel, V., \& Fedorovych, O. (2015) Histolohichna ta histokhimichna kharakterystyka kontaktnoi adhezii "parazyt-khaziain" pry monohenoidozakh koropa. Tvarynnytstvo Ukrainy, 5, 34-38 (in Ukrainian).

Tushnytska, N.Y. (2009) Stan imunnoi systemy i metabolichnyi profil krovi koropa pry zakhvoriuvanniakh krasnukhoiu i riznykh sposobakh yoho likuvannia. $\mathrm{PhD}$ [thesis]. Lviv (in Ukrainian).

Valigurová, A., Hodová, I., Sonnek, R., Koubková, B., \& Gelnar, M. (2011) Eudiplozoon nipponicum in focus: monogenean exhibiting a highly specialized adaptation for ectoparasitic lifestyle. Parasitol Res., 108(2), 383-394. doi: 10.1007/s00436-010-2077-6.

Zurawski, T.H., Mousley, A., Mair, G. R., Brennan, G. P., Maule, A. G., Gelnar, M., \& Halton, D.W. (2001). Immunomicroscopical observations on the nervous system of adult Eudiplozoon nipponicum (Monogenea: Diplozoidae). International Journal for Parasitology, 31(8), 783-792. doi: 10.1016/S00207519(01)00192-8. 